\title{
DEVELOPMENT OF THE REMOTE-PILOTED VEHICLE ALGORITHMIC SUPPORT AND ON-BOARD NAVIGATION COMPLEX STRUCTURE
}

\author{
Mykola Mykyjchuk, Volodymyr Markiv \\ Lviv Polytechnic National University, Department of Measuring Information Technologies
}

Abstract. The article dwells upon the peculiarities of remote piloted vehicles of on-board navigation complex. It is highlighted that total number of the remote-piloted vehicles have increased and as a result the question of their integration into common space with manned aircraft becomes urgent. It is possible only when specified quality of the remote piloted vehicle movement parameters have been determined, including accuracy and interference immunity. It has been highlighted that remote-piloted vehicle equipment is subject to stringent requirements for minimization of cost, mass and size characteristics and power consumption, which are often mutually contradictory, and their implementation in general leads to deterioration of accuracy. The problem of ensuring accuracy and noise immunity when using the general-purpose element base becomes urgent.

Keywords: remote-piloted vehicle, on-board navigation complex, inertial navigation complex, algorithmic suppor

\section{ALGORYTMICZNE SYSTEMY WSPARCIA BEZZALOGOWYCH STATKÓW POWIETRZNYCH I CECHY STRUKTURY POKŁADOWYCH SYSTEMÓW NAWIGACYJNYCH}

\begin{abstract}
Streszczenie. $W$ artykule poruszono zagadnienie pokładowych systemów nawigacyjnych w bezzałogowych statkach powietrznych. Należy podkreślić, że liczba bezzałogowych statków powietrznych wzrosła obecnie na tyle, że integracja bezzałogowych oraz załogowych statków powietrznych we wspólnej przestrzeni powietrznej stała się ważnym i palacym problemem. Jest to możliwe jedynie pod warunkiem uzyskania najwyższej jakości parametry ruchu bezzałogowych statków powietrznych, z odpowiednia dokładnościa i odpornościa na zaktócenia. W artykule podkreślono, że wyposażenie bezzałogowych statków powietrznych jest pod ciagła presją w zakresie minimalizacji kosztów, przystosowania do produkcji masowej, minimalizacji wielkości oraz zużycia energii, które czesto sa ze soba sprzeczne i implementacja których prowadzi do pogorszenia dokładności nawigacji oraz odporności na zakłócenia. Tym samym, zagadnienie zapewnienia precyzji oraz odporności na zakłócenia podczas użytkowania elementów ogólnego przeznaczenia w pokładowych systemach nawigacyjnych $w$ bezzałogowych statkach powietrznych stało się palacym problemem.
\end{abstract}

Słowa kluczowe: bezzałogowy statek powietrzny, pokładowy system nawigacyjny, bezwładnościowy system nawigacyjny, wsparcie algorytmiczne

\section{Introduction}

The theoretical and practical value of the remote-piloted vehicles use is concerned with the development of methods of improvement control quality based on different methods and approaches. They will help to provide better quality of remote-piloted vehicles control.

Robotic technologies are increasingly used in various spheres of life. At the same time, the market of robotic aircraft is developing very dynamically. As the total number of unmanned aerial vehicles grows, it becomes urgent to integrate them into a common space with manned aircraft, which can only be solved if the specified quality of remote-piloted vehicles movement parameters is achieved, including accuracy and noise immunity. Operational standards are under development by authorized civil aviation authorities and are likely to repeat similar requirements for onboard equipment of the civilian aircraft.

Currently, international and domestic markets do not offer specialized serial navigation systems for unmanned aircraft, primarily of the small and middle classes, which meet the requirements for safety of flights in the general airspace. Tight requirements for cost minimization, weight and size characteristics and power consumption are often mutually contradictory, and their performance in general leads to a deterioration in accuracy and noise immunity. The developers of the remote-piloted navigation equipment are faced with the problem of ensuring accuracy and noise immunity when using the general-purpose element base $[1,16,20]$.

To achieve this goal it is important to develop the concept of constructing of the on-board navigation complex and to increase noise immunity with variable structure.

It is necessary to investigate problem of development of algorithmic software and hardware solutions that provide increased accuracy of the flight and the peculiarities of the on-board navigation complex.

The basic requirements for accuracy and range of measurement parameters of orientation and navigation of on-board navigation complexes meet requirements of the inertial satellite navigation system.

\section{Peculiarities of on-board navigation complex construction}

Consistent improvement of techniques, technologies, production development and increased efficiency dramatically changes value of orientations. The main problem concerning remote-piloted vehicles is precise control and data transmission at long distances, because remote-piloted vehicles are under the influence of a variety of factors during the flight:

- weather (temperature, wind direction, humidity),

- the level of radio barriers,

- relief of the region,

- atmospheric pressure

Due to the fact that it is difficult to evaluate these factors the accuracy of remote-piloted vehicles metrology supply, processing speed and data transmission are very important.

It is extremely important to improve the control and localization of remote-piloted vehicles by improving metrological measurements and the reduction of the metrology errors.

In navigation system there is the place for the movement of controlled objects, which are described in relation to a predetermined reference system. The motion of controlled object in any reference system is always purposeful (the trajectory, speed, acceleration and direction of travel are calculated). In real conditions, the various forces and moments disturb (deterministically and randomly) the moving object [4, 7]. Therefore, the navigation process in the systems of traffic control has the following stages $[1,14,15]$ :

- determination of the required law of motion of the object;

- measurement of the characteristics of the actual motion of the object;

- comparison of the parameters of the actual position of the object with the given one and the definition of the deviation;

- the development of control signals (commands) and their transmission to the executive authorities in order to fulfill the prescribed law of motion. 


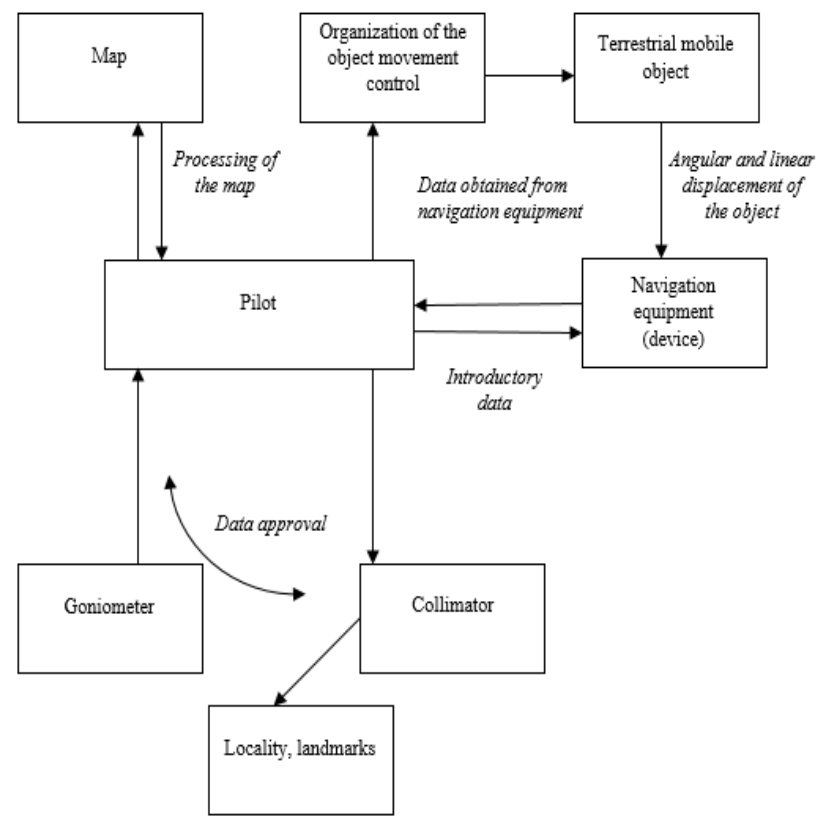

Fig. 1. General scheme of navigation control of terrestrial moving object

General scheme of navigation control of terrestrial moving object is depicted in Fig. 1. This process is as following [14]:

- the commander (driver), using sighting and angle devices, orientation on the ground and the map, prepares the initial data, which is involved into the navigation equipment;

- in the process of motion of an object, navigation equipment automatically determines its linear and angular displacements and produces navigation information that the commander (the driver) takes when choosing a further route of the movement.

For navigational control at the present stage, various technical means and physical principles are used. To obtain navigation information in order to control the movement of the center of mass of an object on its board, various technical means of navigation are set-up.

Specificity of remote-piloted application without terrestrial support under low-altitude flight, while reducing the visibility of signals of navigation satellites of global navigation satellite systems, complicates the problem of accuracy and provision of interference immunity $[13,17]$. [14]:

There are two possible ways of the solution of the problem

- use of the equipment used in manned aircraft (advantage of this approach is the use of waste products and technologies, disadvantage is ignoring the remote-piloted vehicle specificity that makes practically impossible to use it as a part of the remote-piloted vehicle of small and middle classes);

- creation of specialized navigation systems of small and middle-class remote-piloted vehicle in which it is possible to apply inexpensive general-purpose sensors (possibility to maintain algorithms software, and apparatus core of remotepiloted on-board navigation complex based on to the inertial navigation system).

It is necessary to substantiate the concept of construction, development of software and algorithmic support and hardware solutions to improve accuracy, as well as to study the properties of on-board navigation complex with high interference immunity and with variable structure for remote-piloted vehicles $[1,6,19]$.

At the first stage of development of on-board navigation complex it is necessary to justify its structure in accordance with the requirements for the accuracy of determining orientation and navigation parameters, to propose the concept of the development procedure, operation modes, to develop the structure of algorithms for complex information processing, orientation and navigation algorithms, to justify the choice of the hardware of on-board navigation complex.
The basic requirements for the accuracy and range of measurements of orientation and navigation parameters of the on-board navigation complex correspond to the requirements of the inertial-satellite navigation system [14].

The traditional approach to the design of the remote-piloted vehicles involves the following:

- selection of measurers,

- development of orientation and navigation algorithms based on measurer values,

- development of algorithms for complex processing of information.

Such an order is used because of the small volume of sensors and high cost of products. However, the reverse order is more flexible and productive:

- requirements,

- modes of operation

- measurements,

- development of algorithms for complex processing of information,

- development of orientation and navigation algorithms based on measurer values,

- selection of measurers.

It is more convenient due to the lack of mandatory requirements for remote-piloted vehicle navigation equipment and, accordingly, the absence of the need for certification, which gives advantages in the development of algorithmic support and choice of measurers.

When creating remote-piloted vehicle, it is necessary to take into account such critical factors as ensuring the accuracy levels established by the technical specification while minimizing the cost, weight and size characteristics and energy consumption. From this point of view, the optimal method for constructing on-board navigation complex is integration into single complex of sensors and systems with the integration of measurement information. The core of on-board navigation complex should be built on the basis of the free-form inertial navigation system. In order to ensure the piloting tasks, the on-board equipment includes system of air signals $[1,21,22]$.

On the basis of the air signals system and magnetic compass air course counting is performed, which together with the inertial calculation allow to obtain comprehensive solution in an autonomous mode (without the use of GNSS). It is important to include in the on-board navigation complex receiver of GNSS signals. Thus, the ideology of constructing of the on-board navigation complex initially consists in the integration of measurements from the sensors and systems that make up its structure. On-board navigation complex directly consists from inertial sensors, GNSS and magnetic compass receivers and also from interface with air signal system $[9,14,21]$.

Specific types of sensors and systems are selected in accordance with the requirements of software and algorithmic support of on-board navigation complex.

It is based on the sequence of stages:

- requirements,

- operating modes,

- measurements

- development of algorithms for complex processing of information,

- development of orientation and navigation algorithms (based on measurer values and selection of measurers),

- structure of on-board navigation complexes. There are various types of remote-piloted vehicles control system (Fig. 2) [10, 11, 15]:

- manual control when remote-piloted vehicle is under the control of a pilot,

- automated control when the control is made on the basis of the telemetric data,

- automatic control when the control is made on the basis of on the system chosen parameters. 


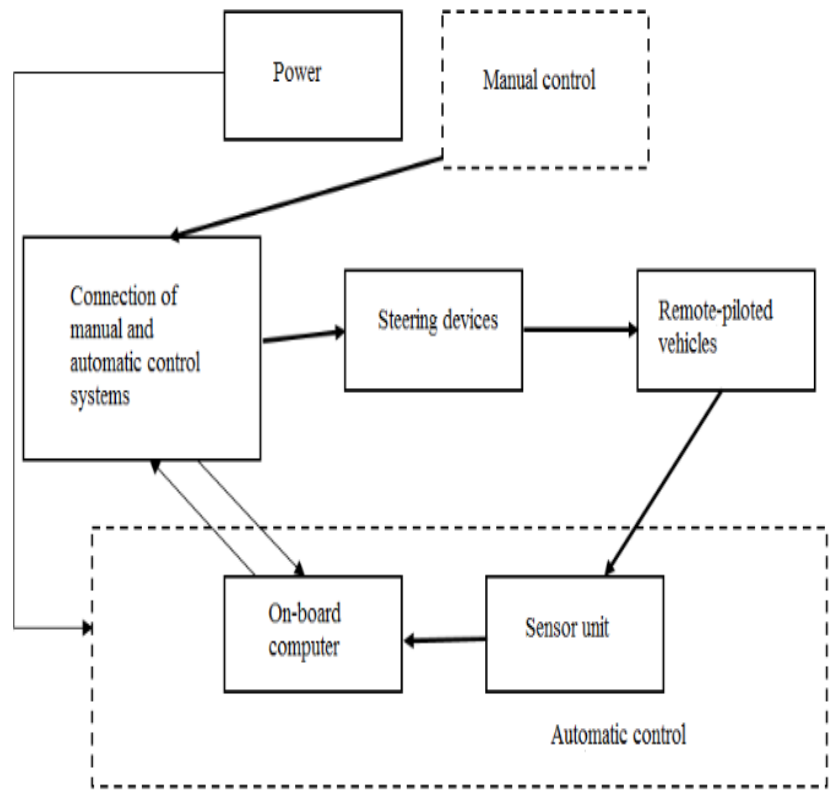

Fig. 2. Control system structure of remote-piloted vehicle

Figure 2 depicts the overall structure of the control system for drone. In particular, the sensor unit contains an inertial module, a tri-axial magnetometer, a receiver of satellite navigation signals, receivers of static and dynamic pressure, an ultrasound altimeter.

\section{On-board navigation complex modes}

The navigation complex is the set of on-board measuring tools and calculators, allowing to determine the location and speed of the aircraft relative to the Earth. None of the existing navigation meters can completely solve these problems, since each of them separately does not provide the necessary accuracy, noise immunity or reliability.

The tasks solved by the navigation complex are diverse. Among them, one of the most important is the reckoning of the path, providing a continuous measurement of the object coordinates. The main disadvantage of the number systems is the deterioration of the accuracy of determining the coordinates with an increase in the working time.

Therefore, to obtain the required accuracy, the numerical coordinates must be continuously or periodically corrected on the basis of information from radio engineering meters, i.e., comprehensive data processing should be carried out.

The basis of navigation complex is inertial navigation system on a gyro-stabilized platform. It measures both the angular position of the aircraft, and the components of acceleration and speed. The speed of the aircraft is also measured by using the airspeed sensor, which is part of the air signal system. The height and speed of its change are measured with the aid of radio altimeter. The signals of these devices are processed in computing device, which is part of a distributed on-board computing system $[8,18]$.

The on-board navigation complex has three main modes: "Initial parameters", "Navigation", "Attitude-and-heading reference" and four auxiliary modes: "Test Control", "Deviation", "Calibration", "Axis Coordination" (Fig. 3) [14].

Modes "Deviation", "Calibration" and "Coordination of axes" can not work simultaneously and outside the mode "Attitude-andheading reference". In the "Test-control" mode, the other modes don't work.

In the "Navigation" mode on-board navigation complex generates and outputs navigation parameters with the required level of accuracy and in full volume. For successful operation of the regime, stable reception of GNSS signals and/or air signal system is required. In the absence of reception of GNSS and/or air signal system during a time interval of a predetermined duration, on-board navigation complex switches to the operation mode of "Attitude-and-heading reference". In this mode, according to the navigation parameters, there are signs of failure, and the orientation parameters are determined with increased errors $[5,6]$.

In the "Attitude-and-heading reference" mode, the angular position of the remote-piloted vehicle relative to the vertical is determined by the measurements of the accelerometers. The error in determining the angles in this mode depends on the flight mode of the remote-piloted vehicle, the maximum accuracy is achieved with a flight close to a straight uniform. In the modes of intensive maneuvering of the remote-piloted vehicle, an error is accumulated, the magnitude of which depends on the duration and intensity of maneuvering. After the reduction of the effect of accelerations and angular velocities, the errors decrease. When start receiving GNSS signals again, the "Navigation" mode is restored. The proposed structure and logic of switching modes fully meets the requirements of the on-board navigation complex and makes it easier to conduct routine maintenance $[1,2,3,14]$.

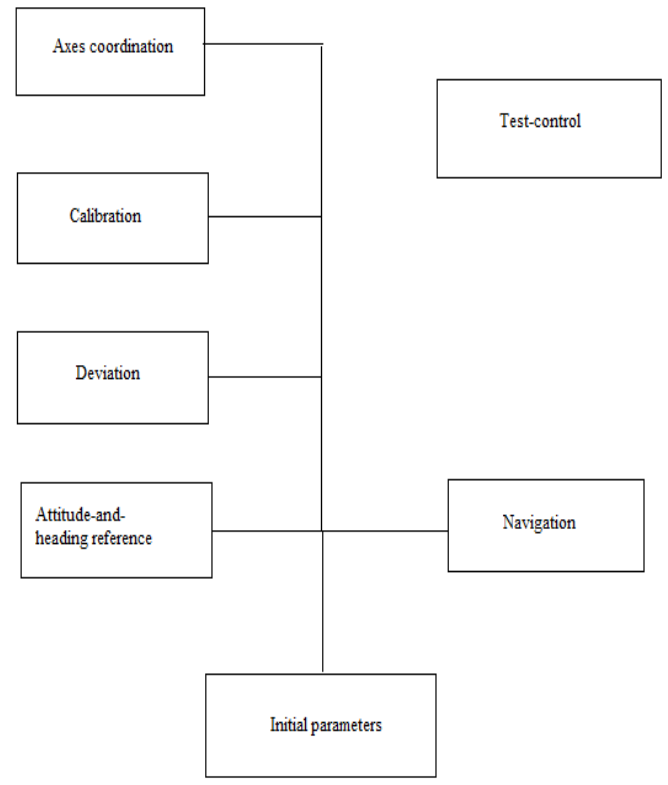

Fig. 3. On-board navigation complex operation modes structure

It is necessary to determine the structure of on-board navigation complex. It includes sensors and systems that allow constructing complex that meets the minimum requirements for determining the orientation and navigation parameters: the inertial module, the satellite navigation receiver GPS and magnetic compass (Fig. 4) $[8,1]$.

The output information of the inertial module are three projections of the absolute angular velocity of rotation and three projections of the apparent acceleration onto the orthogonal axes of the coordinate system. At the same time, it is required to provide a range of measured angular velocities.

The choice of the on-board navigation complex calculator is carried out taking into account the requirements for the interaction interfaces and the functional load [14, 18]:

- control, monitoring and signaling functions for all elements (basic and optional) that are part of the on-board navigation complex,

- collection, processing and transmission of data on internal and external data bases,

- functions for synchronizing the operation of sensors, systems and algorithms,

- implementation of algorithms for orientation, navigation and auxiliary algorithms,

- recording and storage in the non-volatile memory of initial and current settings of parameters of system. 
Interfaces of on-board navigation complex interaction should provide reception and transfer of single discrete commands and data packets exchange with the on-board equipment and implemented navigation complex.

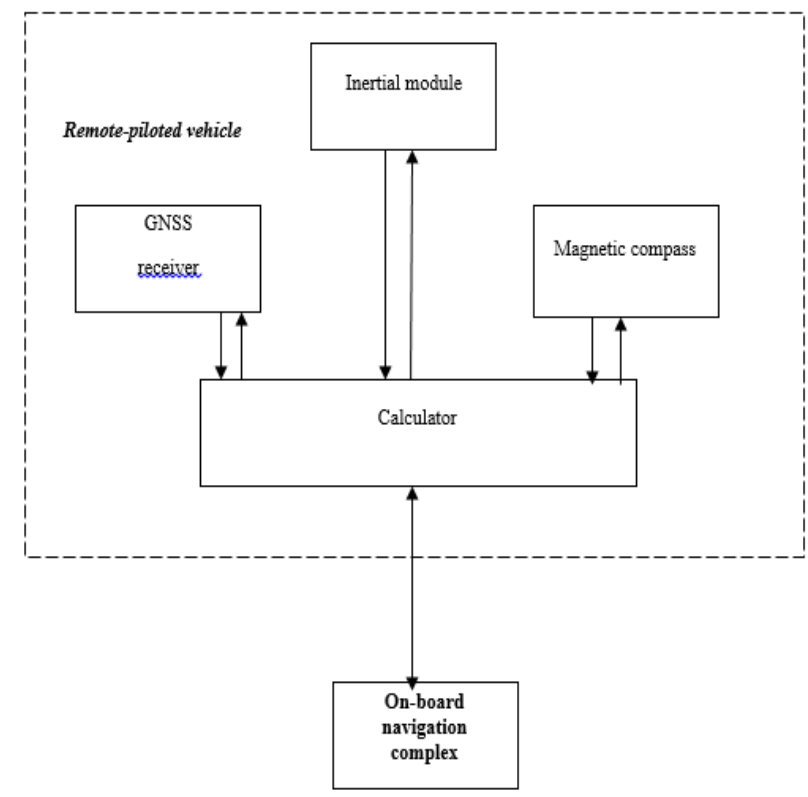

Fig. 4. General structure scheme of the navigation complex

The proposed structure allows to obtain the entire required volume of measurement information for the implementation of orientation and navigation algorithms. It is important to investigate in details the on-board navigation complex structure.

\section{Conclusions}

At the present stage of market economy development remotepiloted vehicles are intensively used in various spheres of scientific life. But there are some hindrances during their movement. Therefore, it is necessary to increase the height of the automatic flight and thus reduce the efficiency of the accomplishment of the tasks.

It is important to analyze the conception of constructing on-board navigation complex, that is the following: determination of requirements, operating modes, selection of measurement types, development of algorithms for complex processing of information, development of orientation and navigation algorithms based on readings of measurers, the choice of measurers.

Structures of algorithmic support of complex processing of information, solving problems of navigation and orientation of the on-board navigation complex are presented.

Hardware structure of the on-board navigation complex, which allows implementing the proposed algorithmic support structure, is proposed.

\section{References}

[1] Austin R.: Unmanned aircraft systems UAVs design, development and Deployment. John Wiley \& Sons Ltd, West Sussex 2010.

[2] Bond L.: Overview of GPS Interference Issues. GPS Interference Symp., Volpe National Transportation System Center 1998, 28-32.

[3] Brown A.K., Yan Lu: Performance Test Results of an Integrated GPS/MEMS Inertial Navigation Package. ION GNSS 17th International Technical Meeting of the Satellite Division, Long Beach, CA, 2004.
[4] Forssel B., Olsen T.: Jamming Susceptibility of Some Civil GPS Receivers. GPS World 1/2003, 54-58.

[5] Grewal M.S., Weill L.R., Andrews A.P.: Global Positioning Systems, Inertial Navigation, and Integration. John Wiley \& Sons, Inc., New York 2001.

[6] Key E.: Technique to Counter GPS Spoofing. Int. Memorandum, MITRE Corporation, 1995

[7] Kim J.-H., Sukkarieh S.: Flight Test Results of GPS/INS Navigation Loop for an Autonomous Unmanned Aerial Vehicle (UAV). ION GPS, 24-27 September 2002, Portland, OR, 2002

[8] Lawrence A.: Modern Inertial Technology (Navigation, Guidance, and Control). Springer-Verlag Inc., New York 1998

[9] Markiv V.: Analysis of remote-piloted vehicles use and control system description. Computer sciences and information technologies 843/2016, 347-351.

[10] Markiv V.: Justification of remote-piloted vehicles use and metrology supply improvement. 5th Int. Scientific Conf. ICS-2016, 20-21.

[11] Martin M.: Non-linear DSGE Models and The Optimized Central Difference Particle Filter 2010, 2-45.

[12] Mukyichuk M., Markiv V.: Peculiarities of Remote-Piloted Vehicles On-Board Navigation Complex Construction. The II International Conference on Computational Linguistics and Intelligent Systems - CoLInS 2018 Lviv, 2018, 161-170.

[13] Mykyichuk M., Markiv V.: Metrology tasks of airphotoshooting by remotepiloted vehicle. Radioelectronics and telecommunications 874/2017, 57-61.

[14] Mykyichuk M., Markiv V.: Peculiarities of fractal analysis of remote-piloted vehicles recognition. VI International Scientific Practical Conference Practical Application of Nonlinear Dynamic Systems for Infocommunication, Chernivtsi 2017, 20-21.

[15] Mykyichuk M., Markiv V.: Peculiarities of the radio signals and hindrances in the navigation system of the remote-piloted vehicles. Informatyka, Automatyka, Pomiary w Gospodarce i Ochronie Środowiska - IAPGOS 8(1)/2018, 40-43.

[16] Neitzel F., Klonowski J.: Mobile 3d mapping with a low-cost UAV system. Int Archives of the Photogrammetry, Remote Sensing and Spatial Information Sciences XXXVIII-1/C22, 67-70.

[17] Roach D.: Dimensionality analysis of patterns: fractal measurements. Computers Geosciences 1993, 849-869.

[18] Salychev O.S.: Applied Inertial Navigation: Problems and Solutions, BMSTU, 2004

[19] Sandau K.: Measuring fractal dimension and complexity - an alternative approach with an application, 1993, 164-176.

[20] Savage P.G.: Strapdown Analytics Part 1\&2. Strapdown Associates, Inc., Maple Plain 2000.

[21] Tsui J. B.-Y.: Fundamentals of Global Positioning System Receivers A Software Approach. John Wiley \& Sons, Inc., New Jersey 2005.

[22] Winkler S., Schulz H.-W., Buschmann M., Vorsmann P.: Testing GPS/INS Integration for Autonomous Mini and Micro Aerial Vehicles. ION GNSS 18th International Technical Meeting of the Satellite Division. Long Beach 2005.

\section{Prof. Mykola Mykyjchuk \\ e-mail: mykolam@ukr.net \\ Director of Computer Technologies, Automation and Metrology Institute, Professor at the Department of Measuring Information Technologies. Research field covers wide variety of methods and means of metrology supply improvement based on metrology indices, development of methods and means of operational control of industrial errors. Author of nearly 150 publications in this research area.}

ORCID ID: 0000-0001-8343-3298

\section{M.Sc. Volodymyr Markiv}

e-mail: vovamarkiv6230@gmail.com

Ph.D. student at the Department of Measuring Information Technologies, specialization in 05.01 .02 "Standardization, certification and metrology supply". Research field covers development of theoretical and methodical bases of the quality characteristics of products and services and the development of metrological supply for measurement and monitoring of certification. Author of nearly 20 publications in this research area.

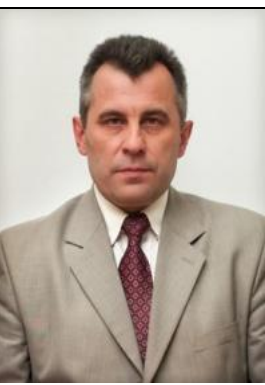

ORCID ID: 0000-0003-0598-593X

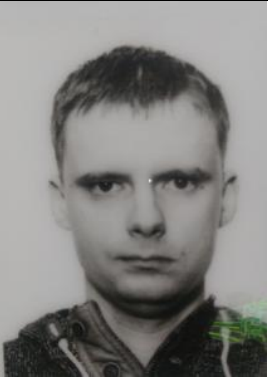

otrzymano/received: 1.10 .2018

przyjęto do druku/accepted: 15.12 .2018 